\title{
Selective feeding of spot, Leiostomus xanthurus, and Atlantic croaker, Micropogonias undulatus, larvae in the northern Gulf of Mexico
}

\author{
John J. Govoni ${ }^{1}$, Peter B. Ortner ${ }^{2}$, Faiza Al-Yamani ${ }^{2}$ \& Leonard C. Hill ${ }^{2}$ \\ ${ }^{1}$ National Marine Fisheries Service, NOAA, Southeast Fisheries Center, Beaufort Laboratory, Beaufort, North Carolina 28516, \\ USA \\ ${ }^{2}$ Atlantic Oceanographic and Meteorological Laboratories, NOAA, Ocean Chemistry and Biology Laboratory, Miami, Florida \\ 33149 , USA
}

\begin{abstract}
When examined in relation to their availability in the plankton, the organisms eaten by larval spot Leiostomus xanthurus and Atlantic croaker Micropogonias undulatus collected in the northern Gulf of Mexico indicated that these larvae feed selectively. Two electivity indices indicated that both small (1.00 to $5.00 \mathrm{~mm}$ ) and large $(5.01$ to $10.00 \mathrm{~mm}$ ) spot larvae selected copepodid and adult copepods (Stages CI to CVI), pteropods, and pelecypods. Small croaker larvae also selected copepodid and adult copepods, as did large croaker larvae. Small and large larvae of both species selected Oncaea $\mathrm{sp}$. from among the copepods, while one or more length categories of either species selected Oithona spp., Paracalanus spp., Corycaeus spp., and Acartia tonsa. Selection appeared to be related not only to the width, but also to the swimming behavior and color of food organisms.
\end{abstract}

\section{INTRODUCTION}

The planktonic larvae of marine fishes make discrete feeding strikes. Feeding strikes comprise the perception and recognition of prey, the flexion of the larva's body axis, and the driving forth of the larva toward the food organism (Hunter 1981). Because feeding strikes are primarily visually elicited and larvae have no retinal cone cells or retinomotor pigment movement (Blaxter 1975), larvae feed primarily during the day (Hunter 1981). Given their perceptive field and swimming speeds, larval fishes may search 12 to $120 \mathrm{l}$ of seawater for food organisms in a $12 \mathrm{~h}$ day (Hunter 1981).

Selection of food from the assortment of organisms that constitute the diet of a fish depends upon availability (the relative abundance of food organisms as they are encountered within the ambit of the fish), along with an interaction of the perception and recognition, capture, and successful ingestion of these organisms (Griffiths 1975, Eggers 1977. Drenner et al. 1978). Among larval fishes the most important factor in food selection is generally held to be the width of food organisms, owing to its influence on ingestion (Detwyler \& Houde 1970, Stepien 1976, Hansen \& Wahl 1981,
Hunter 1981, Uotani et al. 1981, Checkley 1982, Dabrowski \& Bardega 1984, Schmitt in press). Yet, width does not entirely pre-empt other factors that can affect perception, recognition, and capture, e.g. the mobility and color of food organisms (Bowers \& Williamson 1951, Arthur 1976, Teska \& Behmer 1981, Checkley 1982, Peterson \& Ausubel 1984, Stoecker \& Govoni 1984). The larvae of 2 sciaenid fishes, spot Leiostomus xanthurus and Atlantic croaker Micropogonias undulatus, eat tintinnids, pteropods, pelecypods, ostracods, and the egg, naupliar, copepodid, and adult stages of copepods (Govoni et al. 1983). There is reason to believe that spot and Atlantic croaker larvae are selective feeders, as these larvae eat fewer taxa of suitable size than are present in ambient plankton.

Do spot and Atlantic croaker larvae feed selectively, and if so, is their selection influenced solely by width or does the color and mobility of food organisms come into play? We address these questions by comparing the relative proportions of food organisms found in the larvae's guts with those of food organisms in the larvae's habitat, and relate apparent food selection to the size, swimming behavior, and color of food organisms. 


\section{METHODS}

Our sampling protocol was novel in that it allowed the simultaneous collection of both fish larvae and their microzooplanktonic food in small, vertically and horizontally discrete volumes of water. Discrete collections of ichthyoplankton and microzooplankton were made in the northern Gulf of Mexico on 4 cruises, 2 each winter from 1979 to 1981 (Table 1), with a modified multiple opening/closing net and environmental sensing system, MOCNESS (Wiebe et al. 1976). Each of the 9 frames of the MOCNESS was equipped with a 1.0 by $1.4 \mathrm{~m}, 505 \mu \mathrm{m}$ mesh nitex net with a 0.50 by 0.70 $\mathrm{m}, 67 \mu \mathrm{m}$ mesh net nested within. Larval fishes, including spot and Atlantic croaker, were sorted from the collections of both nets, while microzooplankters were sorted only from the collections of the nested nets. In each MOCNESS cast, nets were fished at strata within or just above the thermocline (or midwater, where the water was isothermal), in the middle of the upper mixed layer, and at the surface. At towing speeds of 1.5 $\mathrm{kn}$ and with net fishing durations of 2 to $3 \mathrm{~min}$, each outer net sampled approximately $75 \mathrm{~m}^{3}$ of water, while each nested net sampled approximately $25 \mathrm{~m}^{3}$. Collections were preserved in $5 \%$ formaldehyde buffered with sodium borate.

All spot and Atlantic croaker larvae were measured (notochord length, NL) and their gut contents excised, measured (width), and identified. Of 52 and 50 collec- tions containing spot and Atlantic croaker larvae respectively, we chose 14 and 11 for food-selection analysis. Criteria for this choice were: collections made between 1200 and $2000 \mathrm{~h}$ (Central Standard Time); collections having the greatest number of larvae of both species; and collections having the greatest number of larvae with food organisms identifiable to lower taxa. Furthermore, we considered only larvae with at least 1 food organism in their guts (Table 1). This choice allowed us to examine the greatest number of presumably healthy, actively feeding larvae caught during a time interval that minimized errors due to digestion and defecation; we ignored larvae that were possibly unhealthy or stressed in some unknown way. In the single collection that contained $>30$ spot larvae (No. 12, Table 1), 30 larvae were randomly chosen from a numbered grid by using a table of random numbers.

Microzooplankton collections were split in a Motoda box (Motoda 1959), and subsamples of the resulting aliquots were taken with a Stempel pipette (Van Guelpen et al. 1982). Principal food organisms (those with a product of the percent of the total number of food organisms and the percent frequency of occurrence $\geq 1$ [Govoni et al. 1983]) less than $2.0 \mathrm{~mm}$ long were counted and identified in subsamples. By this procedure the reproducibility of counts was $\pm 15 \%$

The common approach to assessing food selection uses indices of electivity that are functions of the relative proportions of food organisms found in the guts of

Table 1. Collections of spot Leiostomus xanthurus and Atlantic croaker Micropogonias undulatus larvae in the northern Gulf of Mexico. Number of larvae with food organisms in their guts are in parentheses

\begin{tabular}{|c|c|c|c|c|c|c|c|c|}
\hline $\begin{array}{c}\text { Collection } \\
\text { No. }\end{array}$ & Date & $\begin{array}{l}\text { Time } \\
\text { (CST) }\end{array}$ & $\begin{array}{l}\text { Depth } \\
\text { (m) }\end{array}$ & Location & $\begin{array}{r}\text { Nur } \\
\text { Leiostom } \\
1.00-5.00 \mathrm{mr}\end{array}$ & $\begin{array}{l}\text { of } \\
\text { anthurus } \\
1-10.00 \mathrm{~mm}\end{array}$ & $\begin{array}{r}\text { Nu } \\
\text { Micropogo } \\
1.00-5.00 \mathrm{~m}\end{array}$ & $\begin{array}{l}\text { nber of } \\
\text { aias undulatus } \\
5.01-10.00 \mathrm{~mm}\end{array}$ \\
\hline 1 & 12 Dec 1979 & 1224 & 16 & $28^{\circ} 55.0^{\prime} \mathrm{N}, 89^{\circ} 28.0^{\prime} \mathrm{W}$ & & & & $1(1)$ \\
\hline 2 & 12 Dec 1979 & 1755 & 14 & $28^{\circ} 55.0^{\prime} \mathrm{N}, 89^{\circ} 28.0^{\prime} \mathrm{W}$ & $1(1)$ & $1(1)$ & & $2(2)$ \\
\hline 3 & 10 Feb 1980 & 1830 & 7 & $29^{\circ} 25.2^{\prime} \mathrm{N}, 85^{\circ} 37.0^{\prime} \mathrm{W}$ & $2(2)$ & & $2(2)$ & \\
\hline 4 & 10 Feb 1980 & 1849 & 1 & $29^{\circ} 25.2^{\prime} \mathrm{N}, 85^{\circ} 37.0^{\prime} \mathrm{W}$ & $1(1)$ & & $3(2)$ & \\
\hline 5 & 4 Dec 1980 & 1829 & 1 & $28^{\circ} 44.0^{\prime} \mathrm{N}, 89^{\circ} 36.0^{\prime} \mathrm{W}$ & & & $15(15)$ & $1(1)$ \\
\hline 6 & $5 \operatorname{Dec} 1980$ & 1206 & 6 & $28^{\circ} .56 .3^{\prime} \mathrm{N}, 89^{\circ} 27.7^{\prime} \mathrm{W}$ & & & $14(14)$ & \\
\hline 7 & 5 Dec 1980 & 1805 & 13 & $28^{\circ} 55.5^{\prime} \mathrm{N}, 89^{\circ} 27.9^{\prime} \mathrm{W}$ & & & $13(6)$ & \\
\hline 8 & 10 Dec 1980 & 1211 & 9 & $29^{\circ} 25.9^{\prime} \mathrm{N}_{i} 85^{\circ} 375^{\prime} \mathrm{W}$ & $1(1)$ & & & \\
\hline 9 & 10 Dec 1980 & 1217 & 5 & $29^{\circ} 25.9^{\prime} \mathrm{N}, 85^{\circ} 35.7^{\prime} \mathrm{W}$ & $7(5)$ & & & \\
\hline 10 & $10 \mathrm{Dec} 1980$ & 1805 & 11 & $29^{\circ} 25.3^{\prime} \mathrm{N}, 85^{\circ} 37.0^{\prime} \mathrm{W}$ & $6(4)$ & & & \\
\hline 11 & 10 Dec 1980 & 1812 & 6 & $29^{\circ} 25.3^{\prime} \mathrm{N}, 85^{\circ} 37.0^{\prime} \mathrm{W}$ & $6\{4\}$ & & & \\
\hline 12 & $10 \operatorname{Dec} 1980$ & 1821 & 1 & $29^{\circ} 25.3^{\prime} \mathrm{N}, 85^{\circ} 37.0^{\prime} \mathrm{W}$ & $772(30)^{\mathrm{a}}$ & $25(1)$ & & \\
\hline 13 & 12 Feb 1981 & 1930 & 6 & $29^{\circ} 05.2^{\prime} \mathrm{N}, 94^{\circ} 06.0^{\prime} \mathrm{W}$ & $1(1)$ & $1(1)$ & & \\
\hline 14 & 12 Feb 1981 & 1940 & 1 & $29^{\circ} 05.2^{\prime} \mathrm{N}, 94^{\circ} 06.0^{\prime} \mathrm{W}$ & $8(8)$ & $1(1)$ & & \\
\hline 15 & 18 Feb 1981 & 1225 & 26 & $28^{\circ} 49.9^{\prime} \mathrm{N}, 89^{\circ} 16.7^{\prime} \mathrm{W}$ & $1(1)$ & & $1(1)$ & \\
\hline 16 & 19 Feb 1981 & 1206 & 10 & $28^{\circ} 55.4^{\prime} N, 89^{\circ} 29.1^{\prime} W$ & $1(1)$ & & & $2(2)$ \\
\hline 17 & 19 Feb 1981 & 1227 & 1 & $28^{\circ} 55.4^{\prime} N, 89^{\circ} 29.1^{\prime} \mathrm{W}$ & $1(1)$ & $1(1)$ & & \\
\hline 18 & 19 Feb 1981 & 1812 & 6 & $28^{\circ} 549^{\prime} \mathrm{N}, 89^{\circ} 284^{\prime} \mathrm{W}$ & $1(1)$ & & $3(2)$ & $2(2)$ \\
\hline 19 & 19 Feb 1981 & 1823 & 1 & $28^{\circ} 54.9^{\prime} \mathrm{N}, 89^{\circ} 28.4^{\prime} \mathrm{W}$ & & & $1(1)$ & $3(3)$ \\
\hline
\end{tabular}


animals with the relative proportions of food organisms available in the animals' immediate habitat. Electivity indices differ in their mathematical attributes and sensitivities to sampling error, as well as in the inferences that they can support (Lechowicz 1982, Pearre 1982). We used 2 electivity indices, Strauss' L (Strauss 1979. 1982) and Chesson's $\alpha$ (Chesson 1978, 1983), because they reflect different properties of food selection:

$$
\mathrm{L}_{\mathrm{i}}=\mathrm{r}_{\mathrm{i}}-\mathrm{p}_{\mathrm{j}}
$$

and

$$
\alpha_{i}=\frac{r_{i} / p_{i}}{\sum r_{1} / p_{2}}
$$

where $r=$ the relative proportion of food category i in the larva's diet; $\mathrm{p}=$ the relative proportion in the larva's habitat (notation of Lechowicz 1982). L varies linearly between +1 (positive selection) and -1 (negative selection), deviates symmetrically about 0 over the range of relative proportions, and is sensitive to sampling error, especially for relatively rare food organisms, but the effects of this sensitivity are not severe (Strauss 1979). L usually has either a positive or negative value; it is 0 only when the relative proportion of a food organism in the gut equals its relative proportion in the plankton. L simply compares by difference the proportion of a food organism found in the gut of a larva with the proportion found in the larva's habitat. L is influenced by the density (number per unit volume) of food organisms as well as the larva's behavior, i.e. L will increase as the density of a food organism in the plankton decreases even if larvae consume identical numbers of this food organism (Chesson 1983). In contrast, a varies nonlinearly between 0 and +1 , deviates asymmetrically about the reciprocal of the number of food taxa available (the standard for selection), but is similarly sensitive to sampling error (Lechowicz 1982). $\alpha$ is 0 when no individuals of a particular food organism are found in the gut, regardless of the relative proportion of this food organism in the environment. $\alpha$ is derived from models of the probabilities of food organisms encountered and captured (Chesson 1978), and is purported to reflect the invariant selection of food organisms over a range of food densities (Pearre 1982). $\alpha$ does not necessarily change as the density of food organisms changes, unless the behavior of the larva changes (Chesson 1983).

$L$ and $a$ values were calculated for individual larvae and for each food organism. In the computation of mean $L$ and $\alpha$ (and its standards of selection), values from each collection were weighted by the number of larvae of each length category in a collection (Cochran 1977). We considered only the relative proportions of principal food organisms, ignoring food organisms that were never eaten by larvae (thus are obviously not selected) or are rarely eaten (thus are not important diet constituents). Our conclusions therefore relate to selection of particular food organisms only in relation to the other organisms known to contribute to the growth and survival of larvae, and not to absolute food preference.

\section{RESULTS}

Both the mean and the positive skewness of foodorganism width increased as spot and Atlantic croaker larvae grew in length (Fig. 1). Small spot larvae (1.00 to $3.00 \mathrm{~mm} \mathrm{NL}$ ) ate food organisms with width between 20 and $300 \mu \mathrm{m}$, whereas large larvae $(5.01$ to $7.00 \mathrm{~mm}$ NL) ate organisms between 60 and $500 \mu \mathrm{m}$. The food organisms eaten by Atlantic croaker larvae showed a more obvious increase in width as larvae grew; small larvae ( 1.00 to $3.00 \mathrm{~mm} \mathrm{NL}$ ) ate food organisms between 60 and $220 \mu \mathrm{m}$, whereas large larvae $(7.01$ to $9.00 \mathrm{~mm} \mathrm{NL}$ ) ate organisms between 100 and $460 \mu \mathrm{m}$. The increase in positive skewness reflects the addition of wider food organisms to the prevailing diets of larger larvae.

Larvae of both species primarily ate food organisms between 100 and $260 \mu \mathrm{m}$ in width and these widths coincided with the widths of copepod nauplii, copepodid and adult copepods, pteropods, and pelecypods (Fig. 1). Within this range the mean width of food organisms eaten by small larvae coincided with the mean widths of copepod nauplii and copepodid and adult copepods, whereas the mean width of organisms eaten by large larvae coincided more closely with the mean widths of pteropods and pelecypods. Atlantic croaker larvae 7.01 to $9.00 \mathrm{~mm}$ NL were an exception; they ate organisms that were closer in width to barnacle nauplii.

The relative proportion of food organisms eaten by larval spot and Atlantic croaker indicated that larvae frequently ate some food organisms in greater proportions than they occurred in the ambient microzooplankton (Table 2), and weighted mean values for $L$ and $a$ confirmed that these food organisms were selected (Fig. 2). L and a values for copepodid and adult copepods (Stages CI to CVI) indicated selection by all length categories of both species and were the highest values among all food organisms (barnacle nauplii had high $\mathrm{L}$ and $\alpha$ values for large Atlantic croaker larvae, but occurred in only 2 collections). Large spot larvae ate pteropods (primarily Limacina trochiformis) disproportionately in 3 of 4 collections and $\mathrm{L}$ and $\alpha$ values confirmed selection. Values for $\mathrm{L}$ and $\alpha$ indicated that both length categories of spot larvae selected pelecypods (bivalve larvae that were 
transforming to juveniles and were near the end of their planktonic period). Weighted mean $\mathrm{L}$ and $\alpha$ values for small and large spot larvae, calculated without Collection 12 (Table 1), i. e. without the heavy weighting influence of this single collection, also indi- cated selection of copepodid and adult copepods, and pelecypods.

Among the copepods eaten by larvae, only Oncaea sp. (probably $O$. venusta) were eaten in relative proportions higher than the relative proportions of this

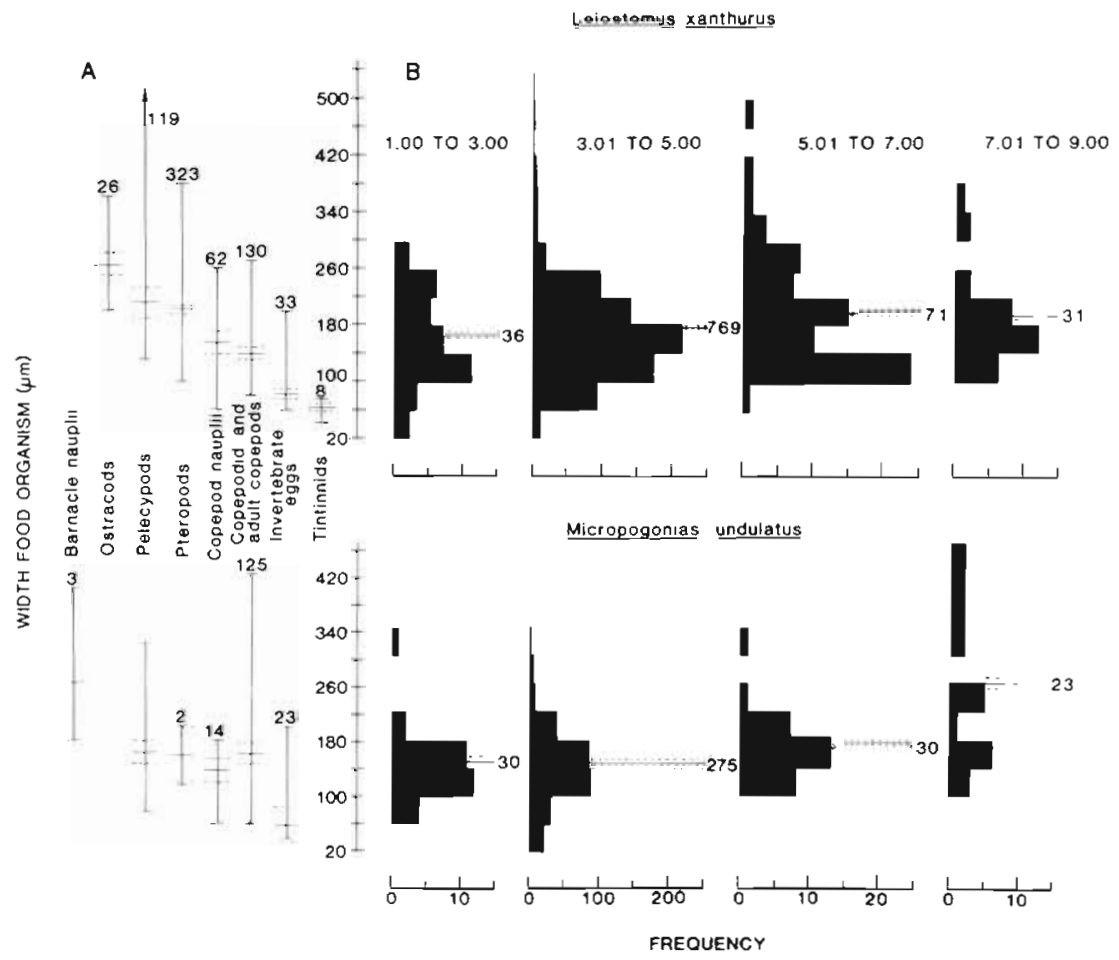

Fig. 1. Food organisms eaten by larval Leiostomus xanthurus and $\mathrm{Mic}$ ropogonias undulatus. (A) Range (vertical line), mean (horizontal solid line). and \pm 2 standard errors of the mean (horizontal broken line) of the width of specific food organisms. Numbers above indicate numbers of observations. (B) Numbers of food organisms of different widths, with mean (solid line) and \pm 2 standard errors (broken lines). Numbers to the right are numbers of observations

Table 2. The fraction of collections in which the relative proportion of food organisms eaten by larval spot Leiostomus xanthurus and Atlantic croaker Micropogonius undulatus exceeded the relative proportion in the ambient plankton

\begin{tabular}{|c|c|c|c|c|}
\hline \multirow[t]{2}{*}{ Food organism } & \multicolumn{2}{|c|}{ Spot } & \multicolumn{2}{|c|}{ Croaker } \\
\hline & $1.00-5.00 \mathrm{~mm}$ & $5.01-10.00 \mathrm{~mm}$ & $1.00-5.00 \mathrm{~mm}$ & $5.01-10.00 \mathrm{~mm}$ \\
\hline Tintinnids & $0 / 12$ & $0 / 4$ & NA & NA \\
\hline Pteropods & $2 / 12$ & $3 / 4$ & $0 / 8$ & $0 / 6$ \\
\hline Pelecypods & $8 / 14$ & $2 / 5$ & $4 / 8$ & $6 / 8$ \\
\hline Ostracods & $3 / 13$ & $1 / 5$ & NA & NA \\
\hline Copepod nauplii & $2 / 14$ & $0 / 5$ & $0 / 8$ & $0 / 6$ \\
\hline Copepodites and adult copepods & $12 / 14$ & $3 / 5$ & $6 / 8$ & $5 / 6$ \\
\hline Eucalanus sp. & NA & NA & $0 / 4$ & $1 / 1$ \\
\hline Undinula sp. & $0 / 1$ & $0 / 0$ & NA & NA \\
\hline Paracalanus spp & $0 / 8$ & $1 / 3$ & $0 / 4$ & $2 / 2$ \\
\hline Temora spp. & $0 / 6$ & $0 / 2$ & $0 / 4$ & $0 / 0$ \\
\hline Acartia tonsa & $0 / 4$ & $0 / 1$ & $1 / 2$ & $0 / 2$ \\
\hline Microsetella sp. & $1 / 6$ & $0 / 2$ & $0 / 0$ & $0 / 2$ \\
\hline Euterpina acutifrons & NA & NA & $0 / 4$ & $0 / 2$ \\
\hline Oithona spp. & $0 / 8$ & $1 / 3$ & $1 / 4$ & $0 / 2$ \\
\hline Saphirella spp. & NA & NA & $0 / 2$ & $0 / 0$ \\
\hline Oncaea sp. & $7 / 8$ & $2 / 3$ & $3 / 4$ & $1 / 2$ \\
\hline Corycaeus spp. & $1 / 7$ & $1 / 2$ & $0 / 4$ & $0 / 1$ \\
\hline Eggs & $2 / 4$ & $0 / 1$ & $1 / 2$ & $1 / 1$ \\
\hline Chaetognaths & NA & NA & 07 & $0 / 6$ \\
\hline Barnacle nauplii & NA & NA & $0 / 6$ & $1 / 2$ \\
\hline
\end{tabular}


Fig. 2. Weighted mean values of electivilarval Leiostomus xanthurus and Micropogonias undulatus. Values of Strauss' (1979) L (closed circles) above zero and values of Chesson's (1978) $\alpha$ (open circles) above the arrows indicate selection. Vertical lines indicate ranges; horizontal lines indicate \pm 2 standard errors ty indices for food organisms eaten by


DISCUSSION

copepod in the plankton in half or more of the collections in which this copepod occurred (Table 2), and weighted mean values of $\mathrm{L}$ and $\alpha$ confirmed that larvae selected this copepod (Fig. 3). An exception, the low mean a value for large Atlantic croaker larvae, resulted from the one of 2 collections (18 and 19, Table 1), where the 2 larvae had not eaten Oncaea sp, and where $\alpha$ consequently was zero. Other copepods were eaten occasionally in disproportionate numbers by some larvae of certain length categories. $L$ and $\alpha$ values indicated that large larvae of both species selectively ate Paracalanus spp. ( $P$. crassirostris, $P$. quasimoto, and $P$. indicus) (Fig. 3). Large spot larvae may have selected Corycaeus spp. (mostly C. amazonicus). (Again, weighted mean $L$ and $\alpha$ values for small and large spot larvae, calculated without Collection 12, indicated selection of Oncaea sp.; mean values for large spot larvae indicated selection of Corycaeus spp. and Paracalanus spp.). Small Atlantic croaker larvae selected Oithona spp. ( $O$. nana and possibly $O$. plumifera and $O$. simplex) and Acartia tonsa along with Oncaea sp. Other copepods were eaten in proportion to or below their relative proportions in the plankton, and $\mathrm{L}$ and $\alpha$ values confirmed no selection.
Three major errors can affect assessments of food selection. The first is error in the estimation of the relative proportions of food organisms in the animal's habitat. The second is error in the estimation of the relative proportion of food organisms in the animal's gut due to differences in digestibility among food organisms. The third is error in the calculated means of electivity indices when the number of available food taxa varies among samples.

As regards the first, differences in distribution in time and space between larval fishes and their microzooplanktonic food can introduce errors in estimates of the relative proportions of food organisms available to fish larvae. Larval fish and their microzooplanktonic food are patchy in spatial distribution (see reviews in Owen 1980, Hewitt 1981, Longhurst 1981), but the scale and intensity of patchiness are grossly different (Houde \& Lovdal 1985); larval fishes are typically 1 or perhaps 2 orders of magnitude less abundant than their microzooplanktonic prey. Moreover, the relative proportion of food organisms in the larva's immediate habitat can change through time as a result of the horizontal and vertical dissociation of microzooplankters and fish larvae (Owen 1980). Because larval fishes feed primarily during daylight hours and digest food and evacuate their guts in 10 or so hours (Govoni et al. 

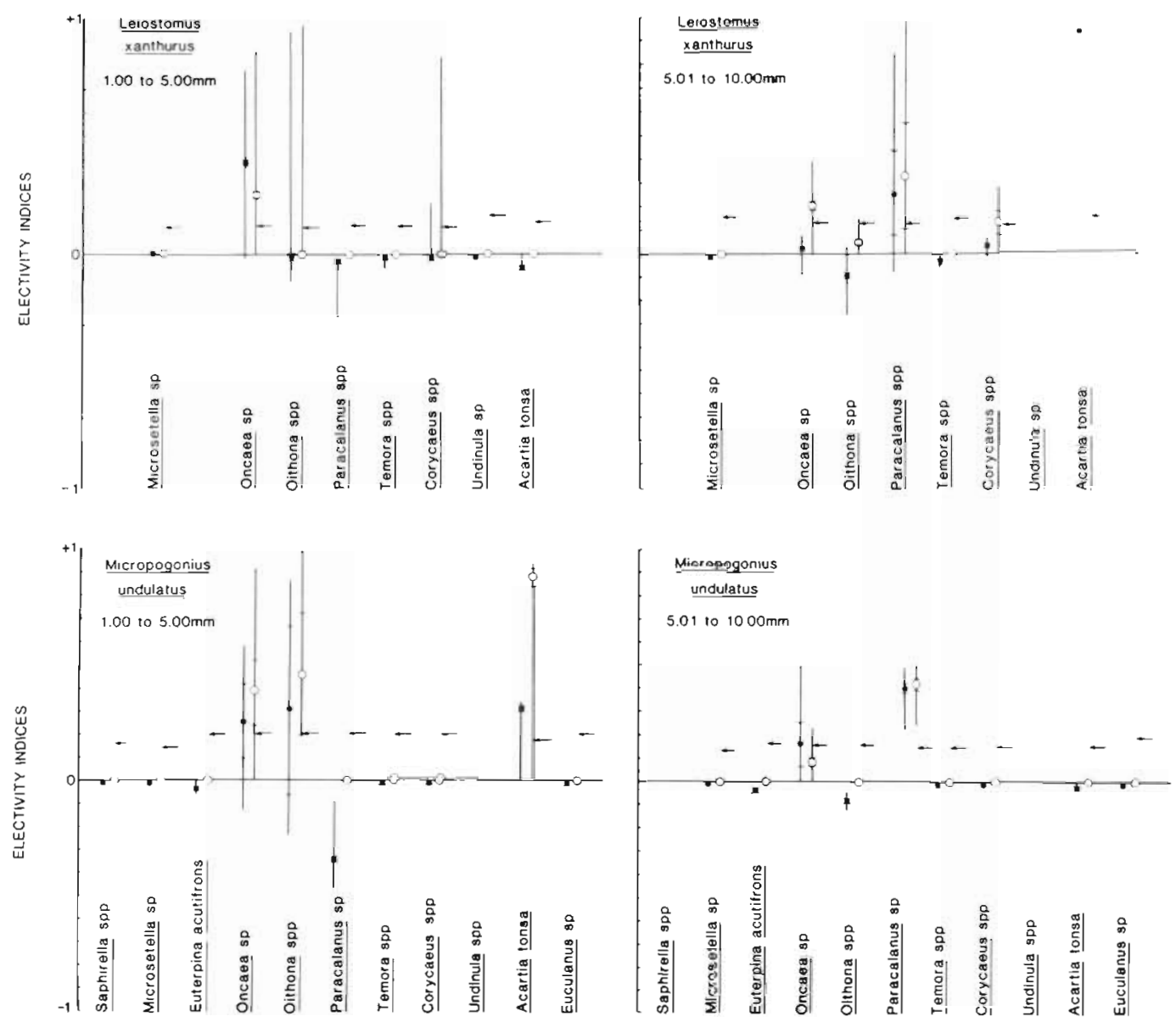

Fig. 3. Weighted mean values of electivity indices for copepods eaten by larval Leiostomus xanthurus and Micropogonias undulatus. Values of Strauss' (1979) L (closed circles) above zero and values of Chesson's (1978) a (open circles) above the arrows indicate selection. Vertical lines indicate ranges; horizontal lines indicate \pm 2 standard errors

in press), the relative proportion of food organisms found in the guts of a larval fish could reflect a microzooplankton assemblage encountered earlier and differing markedly from the assemblage collected along with the larva. The vertically discrete samples in this study horizontally sampled an average of $100 \mathrm{~m}^{3}$ for larval fishes and $25 \mathrm{~m}^{3}$ of the same volume for microzooplankton. While these volumes far exceed the 12 to 120 l possibly searched by a fish larva each day and integrate possible small scale horizontal patchiness of the microzooplankton, they contain numbers of larval fishes barely sufficient for our analysis. Our sampling protocol represents a necessary compromise between the collection of adequate numbers of larval fishes and the sampling of their microzooplanktonic food in a volume of water that comprises the ambit of these larvae.

The second error, erroneous estimates of the relative proportions of food organisms in the guts of larvae, can arise from different rates of passage of tood organisms through larval guts (Coates-Markle 1982). By consider- ing only larvae that had been collected between 1200 and $2000 \mathrm{~h}$, a shorter period on average than that required for gut evacuation, the potential bias of variable digestibility was minimized.

A third potential error is variation in the total number of available food taxa among samples, affecting calculated means of electivity indices. Within our samples, however, the number of food taxa available to larvae did not vary widely: from 4 to 7 for spot larvae when broad taxa were considered (Fig. 2), and from 6 to 9 when copepod genera were included (Fig. 3); 4 to 7 and 4 to 8 respectively for Atlantic croaker larvae.

Food organisms smaller than the maximal acceptable size are selected from the plankton (Fig. 1, 2 \& 3; also Checkley 1982), but larval fishes eat increasingly larger (wider) food organisms as they grow. Copepodid and adult copepods were selected from the microzooplankton by larval spot and Atlantic croaker; small larvae selected the relatively small cyclopoid Oncaea sp., and large larvae selected Oncaea sp. as well as Paracalanus spp., a larger calanoid copepod. Houde \& 
Lovdal (1984) reported that the selection of copepods $<100 \mu \mathrm{m}$ in width decreased while the selection of copepods $>100 \mu \mathrm{m}$ increased as larvae grew.

Size is not the sole factor that influences selection. The copepod nauplii eaten by spot and Atlantic croaker larvae were similar in width to the copepodid and adult copepods eaten (Fig. 1), yet larvae did not select nauplii while they did select copepodites and adults (Fig. 2). Corycaeus spp. were selected only by large spot larvae, although they are cyclopoids similar in size to Oncaea. The Corycaeus and Oncaea species available to larvae (C. speciosus, $C$. clausi, $C$. latus, $C$. lautus, $C$. catus, $C$. amazonicus, $O$. mediterranea, and $O$. venusta) ranged from 0.8 to $2.9 \mathrm{~mm}$ in length (Rose 1933, Gruzov \& Alekseyeva 1970, Turner et al. 1984). The widths of Corycaeus and Oncaea eaten by larvae ranged from 0.1 to $0.3 \mathrm{~mm}$.

Besides size, 2 other attributes of the food organisms selected by spot and Atlantic croaker larvae might enhance their vulnerability: the swimming behavior of these microzooplankters and their color. Calanoid copepods typically swim along a smooth trajectory that is punctuated by occasional short pauses (Shuvayev 1978, Kerfoot et al. 1980, Paffenhöfer \& Knowles 1980, Buskey 1984). Calanoids are characteristically active swimmers (Lowndes 1935, Gauld 1966) with escape responses that attain burst speeds of from 1 to 100 $\mathrm{mm} \mathrm{s}^{-1}$ (Shuvayev 1978), but the relatively small calanoids Acartia and Paracalanus swim in slower, irregular, zig-zag paths (Lowndes 1935, Hardy \& Bainbridge 1954, Gauld 1966, Singarajah 1975, Shuvayev 1978). Cyclopoids typically swim in a hop and sink trajectory that is punctuated with long pauses (Strickler 1975, Shuvayev 1978). While cyclopoids attain burst speeds of 1 to $60 \mathrm{~mm} \mathrm{~s}^{-1}$ in escape responses, they are passive swimmers in comparison to calanoids (Hardy \& Bainbridge 1954, Gauld 1966, Shuvayev 1978). Oithona (Gauld 1966), and probably Oncaea as well, are inactive swimmers with the jerky starts and long pauses that are typical of cyclopoids. As visual feeders, spot and Atlantic croaker larvae may perceive, recognize, and successfully strike these copepods with greater efficiency. The more constant and active swimming along with rapid burst speeds of most other calanoids and cyclopoids may enable them to avoid recognition and capture more frequently. The inability of a fish larvae to close the distance between itself and its prey is thought to be the principal cause of strike failure (Hunter 1972). Behavior also may contribute to the selection of pelecypods and pteropods. Their escape response, closing within their shell and sinking (Morton 1954, Carriker 1961, Gilmer 1974, Chia et al. 1984, Cragg 1980, Mann \& Wolf 1983), may allow for more frequent strike success by larvae. Ostracods, not selected by larvae, have a similar escape response
(Angel 1970), but are much larger and sink rapidly $(9.1$ $\mathrm{mm} \mathrm{s}^{-1}$ ). Rapid sinking may account for lower values of selection inasmuch as sinking decreases the time that the microzooplankter stays within the perceptive and strike field of larval fishes.

Because they are yellow-orange, Oncaea sp., pelecypods, and pteropods may be more readily perceived and recognized than other, colorless microzooplankters. Behavorial response experiments with larval fishes (Blaxter 1975) show high spectral sensitivity in the yellow-orange waveband, 560 to $620 \mathrm{~nm}$. Coastal water, due to the selective scattering of the shorter wavelengths, is maximally transparent to light near yellow-orange, $550 \mathrm{~nm}$ (Jerlov 1976). Spot and Atlantic croaker larvae live in coastal waters and feed near the surface in water irradiated with ample yellow-orange light. For example, at a surface irradiance of about $2.9 \times 10^{3} \mu \mathrm{E} \mathrm{m}^{-2} \mathrm{~s}^{-1}$ (calculated from the solar constant and percentage atmospheric transmission in cloudy temperate regions given by Lüning [1981]), of which about $45 \%$ is included in the 400 to $700 \mathrm{~nm}$ waveband (Anderson 1967), an irradiance of yellow-orange light in the order of 70 to $282 \mu \mathrm{E} \mathrm{m} \mathrm{m}^{-2} \mathrm{~s}^{-1}$ remains at $10 \mathrm{~m}$ (interpolated from Dring [1981] for turbid and clear coastal water). This irradiance is well above the threshold for the perception of food, only $1.8 \times 10^{-2}$ to $1.8 \times 10 \mu \mathrm{E} \mathrm{m}^{-2} \mathrm{~s}^{-1}$ in larval fishes (interpolated from Blaxter [1975] and references therein, with conversions from illuminance to irradiance given in Lüning [1981]). Teska \& Behmer (1981) observed that larval lake whitefish Coregonus clupeaformis select orange copepods, and Byron (1982) observed that planktivorous adult fish select calanoid copepods that are highly colored with orange carotenoid pigments in preference to conspecific copepods that are uncolored.

Copepods typically dominate the marine plankton assemblages of which larval fishes are members (McGowan \& Miller 1980), and larval fishes have apparently evolved to select them over other microplanktonic food organisms. Raisanen \& Applegate (1983) and Rajasilta \& Vuorinen (1983) have shown that the larvae of some freshwater fishes can select copepods. Moreover, spot and Atlantic croaker larvae selected copepods that were consistently present in relatively high densities in the plankton, Oncaea and Paracalanus.

Copepod nauplii, major constituents of the diets of many other larval marine fishes (see review in Turner 1984), were not selected by larval spot and Atlantic croaker (Fig. 1). This observation is consistent with those on other planktonic marine fish larvae of comparable size and morphology, e.g. gadids (CoatesMarkle 1982, Kane 1984), sciaenids (Houde \& Lovdal 1984), gobiids (Houde \& Lovdal 1984), and scombrids (Peterson \& Ausubel 1984). Our data do not explain the 
lack of selection of copepod nauplii by larval fishes. These plankters are well within the acceptable size range of food organisms eaten and coincide in width with the size of the preferred food of spot and Atlantic croaker larvae (Fig. 1). Copepod nauplii swim with a paddling motion along a zig-zag trajectory (Shuvayev 1978). The approach of a predator can elicit an escape response, but this response is no quicker and is perhaps of shorter distance than similar responses of copepodid and adult copepods (Gauld 1966, Shuvayev, 1978).

Differences in selective feeding apparently result in differing diets (Govoni et al. 1983) of the morphologically similar sciaenid larvae, spot and Atlantic croaker. Spot larvae selectively feed on pelecypods, whereas Atlantic croaker larvae do not. The larvae of both species select Oncaea sp. and Paracalanus spp. from ambient copepod assemblages, but small Atlantic croaker larvae, by selecting Acartia tonsa and Oithona spp. in addition to Oncaea and Paracalanus, may be less restrictive in their copepod selection.

Our data indicate that the planktonic larvae of spot and Atlantic croaker feed selectively, but they do not allow a quantitative assessment of the relative contribution of the factors that influence food selection. Nonetheless, these observations do indicate that while food selection is constrained by prey size (a larva can eat only those organisms that it can mechanically ingest), it is also influenced by prey perception, recognition, and capture.

Acknowledgements. We acknowledge with appreciation Dr. P. A. Tester for zooplankton taxonomy, A. J. Chester for statistical advice, and Dr. J. S. Ramus for council on light in the sea. Drs. Tester and D. R. Colby substantially improved the manuscript with their criticisms. This research was supported by a contract from the Ocean Assessment Division, National Ocean Service, NOAA

\section{LITERATURE CITED}

Anderson, M. C. (1967). Photon flux, chlorophyll content, and photosynthesis under natural conditions. Ecology 48: $1050-1053$

Angel, M. V (1970). Observations on the behavior of Conchoecia spinirostris. J. mar biol. Ass. U. K. 50: 731-736

Arthur, D. K (1976). Food and feeding of larvae of three fishes occurring in the California Current: Sardinops sagax, Engraulis mordax, and Trachurus symmetricus. Fish. Bull. U. S. $74: 517-530$

Blaxter, J. H. S. (1975). The eyes of larval fish. In: Ali, M. A. (ed.) Vision in fishes. Plenum Press, New York, p. 427-443

Bowers, A. B., Williamson, D. I. (1951). Food of larvae and early post larval stages of autumn spawning herring in Manx waters. Rep. mar. biol. Stn. Port Erin 63: 17-26

Buskey, E. J. (1984). Swimming pattern as an indicator of the roles of copepod sensory systems in the recognition of food. Mar. Biol. 79: 165-175

Byron, E. R. (1982). The adaptive significance of calanoid copepod pigmentation: a comparative and experimental analysis. Ecology 63: 1871-1886

Carriker, M. R. (1961). Interrelation of functional morphology, behavior, and autecology in early stages of the bivalve Mercenaria mercenaria. J. Elisha Mitchell scient. Soc. 77 : $168-241$

Checkley, D. M. (1982). Selective feeding by Atlantic herring (Clupea harengus) larvae on zooplankton in natural assemblages. Mar Ecol. Prog. Ser. 9: 245-253

Chesson, J. (1978). Measuring preference in selective predation. Ecology 59: 211-215

Chesson, J. (1983). The estimation and analysis of preference and its relationship to foraging models. Ecology 64: $1297-1304$

Chia, F.-S., Buckland-Nicks, J., Young, C. M. (1984). Locomotion of marine invertebrate larvae: a review. Can. J. Zool. 62: $1205-1222$

Coates-Markle, L. J. (1982). Larval and pelagic juvenile feeding ecology of three sympatric Scotian Shelf hakes (Pisces: Gadoidei). M. Sc thesis, University of Guelph, Ontario

Cochran, W G. (1977). Sampling techniques. Wiley, New York

Cragg, S. M. (1980). Swimming behavior of the larvae of Pecten maximum (L.) (Bivalvia). J. mar biol. Ass. U. K. 60: $551-564$

Dabrowski, K., Bardega, R. (1984). Mouth size and predicted food size preferences of larvae of three cyprinid fish species. Aquaculture 40: 41-46

Detwyler, R., Houde, E. D. (1970). Food selection by laboratory-reared larvae of the scaled sardine Harengula pensacolae (Pisces, Clupeidae) and the bay anchovy Anchoa mitchilli (Pisces, Engraulidae). Mar. Biol. 7: 214-222

Drenner, R. W., Strickler, J. R., O'Brien. W. J. (1978). Capture probability: The role of zooplankter escape in the selective feeding of planktivorous fish. J. Fish. Res. Bd Can. 35: $1370-1373$

Dring, M. J. (1981). Chromatic adaptation of phytosynthesis in benthic marine larvae: An examination of its ecological significance using a theoretical model. Limnol. Oceanogr 26: $271-284$

Eggers, D. M. (1977). The nature of prey selection by planktivorous fish. Ecology 58: 46-59

Gauld, D. T. (1966). The swimming and feeding of planktonic copepods. In: Barnes, H. (ed.) Some contemporary studies in marine science. Allen and Unwin, London, p. 313-334

Gilmer, R. W (1974). Some aspects of feeding in thecosomatous pteropod molluscs. J. exp. mar. Biol. Ecol. 15: $127-144$

Govoni, J. J., Boehlert, G. H., Watanabe, Y (in press). The physiology of digestion in fish larvae. Environ. Biol. Fish.

Govoni, J. J., Hoss, D. E., Chester, A. J. (1983). Comparative feeding of three species of larval fishes in the northern Gulf of Mexico: Brevoortia patronus, Leiostomus xanthurus, and Micropogonias undulatus. Mar Ecol. Prog. Ser 13: $189-199$

Griffiths, D (1975). Prey availability and the food of predators. Ecology 56: 1209-1214

Gruzov, L. N. Alexseyeva, L. G. (1970). Weight characteristics of copepods from the equatorial Atlantic. Oceanology 10: $871-879$

Hansen, M. J., Wahl, D. H. (1981). Selection of small Daphnia pulex by yellow perch fry in Oneida Lake, New York Trans. Am. Fish. Soc. 110:64-71

Hardy, A. C, Bainbridge, R. (1954). Experimental observations on the vertical migrations of planktonic animals. $J$ mar biol. Ass. U. K. 33: 409-448

Hewitt, R. (1981). The value of pattern in the distribution of 
young fish. Rapp. P.-v. Réun. Cons. int. Explor. Mer 198: 229-236

Houde, E. D., Lovdal, J. A. (1984). Seasonality of occurrence, foods and food preferences of ichthyoplankton in Biscayne Bay, Florida. Estuar. coast. Shelf Sci. 18: 403-419

Houde, E. D., Lovdal, J. D. A. (1985). Patterns of variability in ichthyoplankton occurrence and abundance in Biscayne Bay, Florida. Estuar. coast. Shelf Sci. 20: 79-104

Hunter, J. R. (1972). Swimming and feeding behavior of larval anchovy, Engraulis mordax. Fish. Bull. U. S. 70: 821-838

Hunter, J. R. (1981). Feeding ecology and predation of marine fish larvae. In: Lasker, R. (ed.) Marine fish larvae: morphology, ecology, and relation to fisheries. Washington Sea Grant Program, Seattle, p. 34-77

Jerlov, M. G. (1976). Optical oceanography. Elsevier, Amsterdam

Kane, J. (1984). The feeding habits of co-occurring cod and haddock larvae from Georges Bank. Mar. Ecol. Prog. Ser. 16: $9-20$

Kerfoot, W. C., Kellog, D. L., Strickler, J. R. (1980). Visual observations of live zooplankters: evasion, escape, and chemical defenses. In: Kerfoot, W. C. (ed.) Evolution and ecology of zooplankton communities. University Press of New England, Hanover, New Hampshire, p. 10-27

Lechowicz, M. J. (1982). The sampling characteristics of electivity indices. Oecologia (Berl.) 52: 22-30

Longhurst, A. R. (1981). Significance of spatial variability. In: Longhurst, A. R. (ed.) Analysis of marine ecosystems. Academic Press, New York, p. 415-441

Lowndes, A. G. (1935). The swimming and feeding of certain calanoid copepods. Proc. zool. Soc. Lond. 687-715

Lüning, K. (1981). Light. In: Lobban, C. S., Wayne, M. J. (ed.) The biology of seaweeds. Blackwell, Oxford, p. 326-355

Mann, R., Wolf, C. C. (1983). Swimming behavior of larvae of the ocean quahog Arctica islandica in response to pressure and temperature. Mar. Ecol. Prog. Ser. 13: $211-218$

McGowan, J. A., Miller, C. B. (1980). Larval fish and zooplankton community structure. Calif. Coop. Fish. Invest. Rep. 21: 29-36

Morton, J. E. (1954). The biology of Limacina retroversa. J mar biol. Ass. U. K. 33: 297-312

Motoda, S. (1959). Devices of simple plankton apparatus. Mem. Fac. Fish. Hokkaido Univ. 7: 73-94

Owen, R. W. (1980). Patterning of flow and organisms in the larval anchovy environment. Intergov. Oceanogr Comm. Workshop Rep. (FAO, UNESCO, Lima) 28: 167-200

Paffenhöfer, G.-A., Knowles, S. C. (1980). Omnivorousness in marine planktonic copepods. J. Plankton Res. 2: 255-365

Pearre, S. (1982). Estimating prey preference by predators: uses of various indices, and a proposal of another based on $\chi^{2}$. Can. J. Fish. Aquat. Sci. 39: 914-923

Peterson, W. T., Ausubel, S. J. (1984). Diets and selective feeding by larvae of Atlantic mackerel Scomber scombrus on zooplankton. Mar Ecol. Prog. Ser 17:65-75
Raisanen, G. A., Applegate, R. L. (1983). Selection of live food by captive yellow perch larvae. Prog. Fish-Cult. 45: $172-174$

Rajasilta, M., Vuorinen, I. (1983). A field study of prey selection in planktivorous fish larvae. Oecologia (Berl.) 59: $65-68$

Rose, M. (1933). Copépodes pélagiques. Faune Fr. 26: 1-374

Schmitt, P. D. (in press). Feeding by larvae of Hypoatherina tropicalis (Pisces: Atherinidae) and its relation to prey availability in One Tree Lagoon, Great Barrier Reef, Australia. Environ. Biol. Fish.

Singarajah, K. V (1975). Escape reactions of zooplankton: effects of light and turbulence. J. mar. biol. Ass. U. K. 55: $627-639$

Shuvayev, Yu. D. (1978). Movements of some planktonic copepods. Hydrobiol. J. 14: 32-36

Stepien, W. P. (1976). Feeding of laboratory-reared larvae of the sea bream Archosargus rhomboidali (Sparidae). Mar. Biol. 38: 1-16

Stoecker, D. K., Govoni, J. J. (1984). Food selection by young larval gulf menhaden (Brevoortia patronus). Mar. Biol. 80: 299-306

Strauss, R. E. (1979). Reliability estimates for Ivlev's electivity index, the forage ratio, and a proposed linear index of food selection. Trans. Am. Fish. Soc. 108: 344-352

Strauss, R. E. (1982). Influence of replicated subsamples and subsample heterogeneity on the linear index of food selection. Trans. Am. Fish. Soc. 111: 517-522

Strickler, J. R. (1975). Swimming of planktonic Cyclops species (Copepoda, Crustacea): pattern, movement and their control. In: Wu, T. Y.-T, Brokaw, C. J., Brennen, C. (ed.) Swimming and flying in nature, Vol. 2. Plenum, New York, p. 599-613

Teska, J. D., Behmer, D. J. (1981). Zooplankton preference of larval lake whitefish. Trans. Am. Fish. Soc. 110: 459-461

Turner, J. T (1984). The feeding ecology of some zooplankton that are important prey items of larval fish. NOAA. Tech. Rep. NMFS 7

Turner, J. T., Tester, P. A., Conley, W. J. (1984). Zooplankton feeding ecology: predation by the marine cyclopoid copepod Corycaeus amazonicus F. Dahl upon natural prey. J. exp. mar Biol. Ecol. 84: 191-202

Uotani, I., Matsuzaki, K., Makino, Y., Noda, K., Inamura, O., Horikawa, M. (1981). Food habits of larvae of tunas and their related species in the area northeast of Australia. (In Japanese with English summary.) Bull. Jap. Soc. scient. Fish. 47: 1165-1172

Van Guelpen, L., Markle, D. F., Duggan, D. J. (1982). An evaluation of accuracy, precision, and speed of several zooplankton subsampling techniques. J. Cons. int. Explor. Mer 40: 226-236

Wiebe, P. H., Burt, K. H., Boyd, S. H., Morton, A. W. (1976). A multiple opening/closing net and environment sensing system for sampling zooplankton. J. mar. Res. 34: 313-316 